\title{
Pathological Survey on Early Leaf Blight of Tomato and In Vitro Effect of Culture Media, Temperature and $\mathrm{pH}$ on Growth and Sporulation of Alternaria solani
}

\author{
I. Parvin1, C. Mondal1, S. Sultana1, N. Sultana' ${ }^{2}$ F. M. Aminuzzaman ${ }^{3 *}$ (]) \\ ${ }^{1}$ Agrotechnology Discipline, Khulna University, Khulna, Bangladesh \\ ${ }^{2}$ Department of Plant Pathology, Bangladesh Agricultural University, Mymensingh, Bangladesh \\ ${ }^{3}$ Department of Plant Pathology, Faculty of Agriculture, Sher-e-Bangla Agricultural University, Sher-e-Bangla Nagar, \\ Dhaka, Bangladesh \\ Email: ^aminsaupp@yahoo.com
}

How to cite this paper: Parvin, I., Mondal, C., Sultana, S., Sultana, N. and Aminuzzaman, F.M. (2021) Pathological Survey on Early Leaf Blight of Tomato and In Vitro Effect of Culture Media, Temperature and $\mathrm{pH}$ on Growth and Sporulation of Alternaria solani. Open Access Library Journal, 8: e7219.

https://doi.org/10.4236/oalib.1107219

Received: February 9, 2021

Accepted: March 28, 2021

Published: March 31, 2021

Copyright $\odot 2021$ by author(s) and Open Access Library Inc.

This work is licensed under the Creative Commons Attribution International License (CC BY 4.0).

http://creativecommons.org/licenses/by/4.0/

\begin{abstract}
Alternaria solani causing early blight of tomato is a serious disease, causing $50 \%$ to $86 \%$ losses in fruit yield and $20 \%$ to $40 \%$ losses in seedling establishment. Pathological survey, etiology and physiological characterization of the causal organism are necessary to formulate effective management strategy. Therefore, present study was conducted to determine the incidence and severity of early leaf blight of tomato in some selected area of Bangladesh and to evaluate the effect of different culture media on radial mycelial growth and sporulation as well as the effect of $\mathrm{pH}$ and temperature on mycelial growth. Survey was conducted in five upazilas of Bogura district and typical early blight disease sample was collected from surveyed field and Germplasm Centre, Agrotechnology Discipline, Khulna University, Khulna. Seven different culture media were used namely Potato Dextrose Agar (PDA), Richard's Agar (RA), Waskman Agar (WA), Corn meal Agar (CA), Asthana and Hawker's Agar (AHA), Oat Meal Agar (OMA), V-8 Juice Agar Medium (VJAM) and seven different $\mathrm{pH}$ level such as 5.0, 5.5, 6.0, 6.5, 7.0, 7.5 and 8.0 were used and also exercised five distinct temperatures such as $20^{\circ} \mathrm{C}, 25^{\circ} \mathrm{C}, 30^{\circ} \mathrm{C}, 35^{\circ} \mathrm{C}$ and $40^{\circ} \mathrm{C}$ to appraise cultural characters, mycelial growth and sporulation of A. solani. Cultural characters such as colony color, colony diameter, growth margin, growth surface and margin topography showed distinguished variation in culture media. Among the seven different media V-8 Juice Agar Medium gave not only maximum mycelial growth $(73.10 \mathrm{~mm})$ but also highest sporulation $\left(2000\right.$ spores $\mathrm{ml}^{-1}$ ). The optimum $\mathrm{pH}$ for maximum mycelial
\end{abstract}


growth ranged to $5.5-6.5$. But maximum mycelial growth $(71.70 \mathrm{~mm})$ was observed in $\mathrm{pH}$. Whereas, the mycelial growth was favored by $20^{\circ} \mathrm{C}-30^{\circ} \mathrm{C}$ temperature but $25^{\circ} \mathrm{C}$ temperature provided highest mycelial growth $(72.20$ $\mathrm{mm}$ ). However, temperature above $40^{\circ} \mathrm{C}$ was found adverse for the growth of tested fungus.

\section{Subject Areas}

Agricultural Science

\section{Keywords}

Alternaria solani, Tomato, Early Blight, Incidence, Severity, Culture Media, Temperature, $\mathrm{PH}$

\section{Introduction}

Tomato (Lycopersicon esculentum Mill) is one of the most popular vegetables in Bangladesh (Chowdhury, 1979) [1]. And consumed raw, grind into paste to make soup or sliced, dried and grind into powder or grind to produce tomato juice (Musa et al., 2007) [2]. It's not only popular but also it is ranked as the third most important vegetable crop in our country. Recent statistics in Bangladesh demonstrated that the area under tomato cultivation was 67,535 acre with a total production of 368,121 metric tons during 2015-2016 having an average yield $13.46 \mathrm{t} / \mathrm{ha}$ (BBS, 2016) [3]. On the other hand, in the year 2016, world's total tomato production was estimated to be 177 million tons from 4.8 million hectare (FAOSTAT, 2016) [4]. Moreover, average yield of tomato in Bangladesh is very low as compared to neighboring country like China (56.2 t/ha) and India (24.2 t/ha) (Halder et al., 2003) [5].

Among the various causes of lowering yield in comparison to neighbors, diseases are one of the most significant reasons. There are several diseases on tomato caused by fungi, bacteria, viruses, nematodes and abiotic factors (Balanchard, 1992) [6]. Among the fungal diseases, early blight also known as target spot disease incited by Alternaria solani is one of the world's most catastrophic diseases. The causal organism is air borne and soil inhabiting and is responsible for early blight, collar rot and fruit rot of tomato (Datar and Mayee, 1981) [7].

The first symptoms of early blight are small, dark, necrotic lesions that usually appear on the older leaves and spread upward as the plants become older. As lesions enlarge, they commonly have concentric rings with a target-like appearance, and they are often surrounded by a yellowing zone. The disease appears on leaves, stems, petiole, twig and fruits under favorable conditions resulting in defoliation, drying off of twigs and premature fruit drop and thus causing loss from $50 \%$ to $86 \%$ in fruit yield (Mathur and Shekhawat, 1986) [8].

In severe epidemics, $A$. solani causes premature defoliation, weakens the plants and exposes the fruit to injury from sunscald. When they lead to collar rot 
creates $20 \%$ to $40 \%$ seedling losses in the field (Sherf and MacNab, 1986) [9]. This fruit and seedling damage causing pathogen is previously known as $A$. porri f. sp. solani (Neergaard, 1945) [10]. The conidia of $A$. solani are muriform and beaked (Neergaard, 1945; Ellis and Gibson, 1975) [10] [11]. Like other members of the genus Alternaria, A. solani has transverse and longitudinal septate conidia, multinucleate cells, and dark-colored (melanized) cells. These melanins protect against adverse environmental conditions including resistance to microbes and hydrolytic enzymes (Rotem, 1994) [12].

It is very difficult to manage, due to its broad host range, extreme variability in pathogenic isolates and prolonged active phase of the disease cycle. Moreover, A. solani requires several specific compounds for their growth, although the fungus is cosmopolitan in nature. However, the nutrient requirements for good growth of the fungus do not confirm the nutrient requirements for good sporulation. For example, Koley and Mahapatra (2015) [13] claimed that Alternaria solani grew well on PDA and Richard's broth, on the other hand oat meal agar was best for sporulation. Various media compositions also influence the different colony morphology of $A$. solani. Morphological characterization is the classical approaches to distinguish fungal species that is one of the main requisite of fungal taxonomy (Diba et al., 2007 and Zain et al., 2009) [14] [15].

The mycelial growth of fungus varies not only with different culture media but also with $\mathrm{pH}$ and temperature. Considering these facts, impact of different range of temperature and $\mathrm{pH}$ on growth and sporulation of Alternaria solani in solid and liquid medium have been reported by Stevenson and Packer (1988) [16]; Rodriguez and Santa (1991) [17]; Prasad et al. (1973) [18]; Rath and Padhi (1973) [19] etc. For instance, Yunhui et al. (1994) [20] observed that optimum temperature for fungal growth was $23^{\circ} \mathrm{C}-28^{\circ} \mathrm{C}$ and $\mathrm{pH}$ was $6-8$. The present research work was therefore conducted 1 ) to determine incidence and severity of early blight of potato in some selected area; 2) to find out effective growth and sporulating media for Alternaria solani; and 3) to determine suitable $\mathrm{pH}$ and temperature for mycelial growth of Alternaria solani.

\section{Materials and Methods}

The survey on early blight of tomato was conducted during 2017-2018 season in five upazilas of Bogura district, Bangladesh. Laboratory experiments were conducted in the Plant Protection Laboratory of Agrotechnology Discipline, Khulna University, Khulna, Bangladesh during January, 2018 to October, 2018. The effect of different culture media, $\mathrm{pH}$ and temperature were tested on the radial mycelial growth, sporulation of Alternaria solani causal agent of early blight disease of tomato.

\subsection{Survey and Sampling of Diseased Specimen}

The survey was conducted during winter season (December to March), 2017-2018. The survey was done in local farmer fields in the selected villages under each 
upazila of Adamdighi, Bogura sadar, Dupchanchia, Kahalu and Nandigram of Bogura district of Bangladesh. Five tomato fields were randomly selected under each upazila. Incidence and severity of early leaf blight was determined onapproximately 30 decimal tomato field area of each field under each upazila. Typical symptomaticearly blighted tomato leaf samples were collected from survey area and Germplasm Centre, Agrotechnology Discipline, Khulna University, Khulna in plastic bag and stored in refrigerator at $4^{\circ} \mathrm{C}$ for further study.

\subsection{Isolation of Alternaria solani from Diseased Leaf}

Diseased leaves were cut into about $5 \mathrm{~mm}$ size after washing containing yellow hallows where healthy and diseased tissues remain together. The cut leaf pieces were first thoroughly washed by sterilized distilled water and then transferred to $0.1 \%$ sodium hypocloride $(\mathrm{NaOCl})$ solution and kept there for 2 - 3 minutes. Excess $\mathrm{NaOCl}$ was removed by soaking with sterilized blotting paper. The cut pieces were then placed onto sterilized Potato Dextrose Agar (PDA) medium in glass petridishes and incubated in room temperature $\left(25^{\circ} \mathrm{C} \pm 1^{\circ} \mathrm{C}\right)$ until mycelium formation. All works were done in an aseptic condition.

\subsection{Pure Culture and Preservation of Alternaria solani}

To obtain pure culture of Alternaria solani, a hyphal tip from subculture was transferred aseptically to PDA petridish by using a sterile fine needle. After that the petridish was sealed with the paraflim to avoid contamination hence incubated in an incubator at a temperature of $25^{\circ} \mathrm{C} \pm 1^{\circ} \mathrm{C}$ for 6 days. After producing white cottony mycelial advanced hyphae were collected and transferred aseptically on petri dish containing $\mathrm{PDA}$ with $\mathrm{pH} 7$ and incubated at room temperature $\left(25^{\circ} \mathrm{C} \pm 1^{\circ} \mathrm{C}\right)$ for 6 days then preserved at $4^{\circ} \mathrm{C}$ in a refrigerator for further use.

\subsection{Pathogenicity Test}

The excised leaves were surface disinfected by dipping in $70 \%$ ethanol for 30 second and placed onto moistened blotting paper in a petridish. Each leaf was inoculated with conidial suspension of Alternaria solani having $1 \times 10^{6}$ conidia/ml suspension and incubated at $25^{\circ} \mathrm{C} \pm 1^{\circ} \mathrm{C}$ for appearance of symptoms.

\subsection{Preparation of Growth Media}

The cultural characters of the pathogen were studied upon multiplication on the following solid media. The culture media were prepared by following the procedure demonstrated by Dhingra and Sinclair (1995) [21] except PDA. The materials of different media are given on Table 1.

\subsection{Procedures of Media Preparations}

PDA was prepared following the standard procedure (Anonymous, 1968) [22]. $200 \mathrm{~g}$ peeled potato was cut into slice and boiled in $1000 \mathrm{ml}$ distilled water then sieved into a beaker and $20 \mathrm{~g}$ dextrose was mixed with it, after that $15 \mathrm{~g}$ agar was 
Table 1. Ingredients of different culture media used for characterization of Alternaria solani.

\begin{tabular}{|c|c|c|c|c|c|c|c|}
\hline Components & $\begin{array}{c}\text { Potato } \\
\text { Dextrose } \\
\text { Agar (PDA) }\end{array}$ & $\begin{array}{l}\text { Richard's } \\
\text { Agar (RA) }\end{array}$ & $\begin{array}{l}\text { Waskman } \\
\text { Agar (WA) }\end{array}$ & $\begin{array}{l}\text { Corn meal } \\
\text { Agar (CA) }\end{array}$ & $\begin{array}{l}\text { Asthana and } \\
\text { Hawker's } \\
\text { Agar (AHA) }\end{array}$ & $\begin{array}{l}\text { Oat } \\
\text { Meal Agar } \\
\text { (OMA) }\end{array}$ & $\begin{array}{l}\text { V-8 Juice } \\
\text { Agar Medium } \\
\text { (VJAM) }\end{array}$ \\
\hline Potato & $200 \mathrm{~g}$ & $10 \mathrm{~g}$ & - & - & - & - & $34 \mathrm{~g}$ \\
\hline Dextrose/glucose & $20 \mathrm{~g}$ & - & $10 \mathrm{~g}$ & $20 \mathrm{~g}$ & $10 \mathrm{~g}$ & - & $20 \mathrm{~g}$ \\
\hline Agar & $15 \mathrm{~g}$ & $15 \mathrm{~g}$ & $20 \mathrm{~g}$ & $15 \mathrm{~g}$ & $20 \mathrm{~g}$ & $20 \mathrm{~g}$ & $20 \mathrm{~g}$ \\
\hline Potassium nitrate $\left(\mathrm{KNO}_{3}\right)$ & - & - & - & - & - & - & - \\
\hline Potassium monobasic phosphate $\left(\mathrm{KH}_{2} \mathrm{PO}_{4}\right)$ & - & $5 \mathrm{~g}$ & $1 \mathrm{~g}$ & - & $1.75 \mathrm{~g}$ & - & - \\
\hline Magnesium sulphate $\left(\mathrm{MgSO}_{4} \cdot 7 \mathrm{H}_{2} \mathrm{O}\right)$ & - & $2.5 \mathrm{~g}$ & $0.5 \mathrm{~g}$ & - & $0.75 \mathrm{~g}$ & - & - \\
\hline Ferric chloride $\left(\mathrm{FeCl}_{3} \cdot 6 \mathrm{H}_{2} \mathrm{O}\right)$ & - & $0.02 \mathrm{~g}$ & - & - & - & - & - \\
\hline Sucrose $\left(\mathrm{C}_{12} \mathrm{H}_{22} \mathrm{O}_{11}\right)$ & - & $50 \mathrm{~g}$ & - & - & - & - & - \\
\hline Potassium nitrate $\left(\mathrm{KNO}_{3}\right)$ & - & $10 \mathrm{~g}$ & - & - & $3.5 \mathrm{~g}$ & - & - \\
\hline Potassium monobasic phosphate $\left(\mathrm{KH}_{2} \mathrm{PO}_{4}\right)$ & - & $5 \mathrm{~g}$ & - & - & - & - & - \\
\hline Magnesium sulphate $\left(\mathrm{MgSO}_{4} \cdot 7 \mathrm{H}_{2} \mathrm{O}\right)$ & - & $2.5 \mathrm{~g}$ & - & - & - & - & - \\
\hline Ferric chloride $\left(\mathrm{FeCl}_{3} \cdot 6 \mathrm{H}_{2} \mathrm{O}\right)$ & - & $0.02 \mathrm{~g}$ & - & - & - & - & - \\
\hline Sucrose $\left(\mathrm{C}_{12} \mathrm{H}_{22} \mathrm{O}_{11}\right)$ & - & $50 \mathrm{~g}$ & - & - & - & - & - \\
\hline Bacto-peptone & - & - & $5 \mathrm{~g}$ & - & - & - & - \\
\hline Cornmeal extract & - & - & - & $20 \mathrm{~g}$ & - & - & - \\
\hline Oats & - & - & - & - & - & $60 \mathrm{~g}$ & - \\
\hline $\begin{array}{l}\text { beets, celery, carrots, lettuce, parsley, } \\
\text { watercress, spinach, and tomato } \\
\text { [ }>85 \% \text { tomato juice]. }\end{array}$ & - & - & - & - & - & - & $34 \mathrm{~g}$ \\
\hline $\mathrm{CaCO}_{3}$ & - & - & - & - & - & - & $3 \mathrm{~g}$ \\
\hline Distilled water & $1000 \mathrm{ml}$ & $1000 \mathrm{ml}$ & $1000 \mathrm{ml}$ & $1000 \mathrm{ml}$ & $1000 \mathrm{ml}$ & $1000 \mathrm{ml}$ & $1000 \mathrm{ml}$ \\
\hline
\end{tabular}

added with it. The beaker was then placed on a heater with magnetic stirrer and then adjusted to $1000 \mathrm{ml}$ by distilled water. Similar procedure was conducted in preparing cornmeal extract. In case of RA, WA and AHA agar was melted in 500 $\mathrm{ml}$ distilled water and rest of the ingredients was thoroughly dissolved in another $500 \mathrm{ml}$ distilled water. In respect of oat meal agar medium, oat was boiled in $500 \mathrm{ml}$ distilled water for 30 minutes, filtered through muslin cloth, agar was melted in another $500 \mathrm{ml}$ distilled water. Both the preparations of all the media were mixed and the final volume was made up to $1000 \mathrm{ml}$ and then autoclaved at $121^{\circ} \mathrm{C}$ temperature for 20 minutes. For one liter VJAM medium, at first vegetable extracts were mixed with heating distilled water. After 15 minutes boiling agar, dextrose and calcium carbonate were mixed with proper proportion. Then this medium was autoclaved at $121^{\circ} \mathrm{C}$ for 20 minutes.

\subsection{Preparation of PDA Media at Different $\mathrm{pH}$}

Seven different pH levels namely 5.0, 5.5, 6.0, 6.5, 7.0, 7.5 and 8.0 were taken as treatments. Hundred (100) ml PDA was taken in $250 \mathrm{ml}$ conical flask. Different 
$\mathrm{pH}$ were adjusted by adding either $0.1 \mathrm{~N} \mathrm{HCl}$ or $0.1 \mathrm{~N} \mathrm{NaOH}$ and measured by $\mathrm{pH}$ meter.

\subsection{Preparation of PDA Media for Culture in Different Temperature}

Five temperature from $20^{\circ} \mathrm{C}-40^{\circ} \mathrm{C}\left(5^{\circ} \mathrm{C}\right.$ intervals) were used to incubate PDA petri dish cultures of the selected $A$. solani isolates to find out the optimum temperature as well as the lowest and highest temperatures at which fungal growth occurred.

\subsection{Inoculation and Incubation}

All these treatment were conducted in five replications. Advanced hyphae of 6 days old culture was used for inoculation. A $5 \mathrm{~mm}$ block of the mycelium was cut with flame sterilized cork borer $(5 \mathrm{~mm})$. The mycelial blocks were taken from the edge of the colony. Each mycelial block was placed upside down at the centre of each petridish. All this operation was done under aseptic condition. The inoculated petridishes were kept in the growth chamber at room temperature $\left(25^{\circ} \mathrm{C} \pm 1^{\circ} \mathrm{C}\right)$ until the mycelia touch the edge of petridishes.

\subsection{Measurement of the Mycelial Growth of Alternaria solani}

Mycelial growth of the isolates was measured by averaging the two dimensions (90 mm petridish) taken for each colony after six days of inoculation for different growth media, $\mathrm{pH}$ and temperature.

\subsection{Counting of Spore}

The number of spores was counted by dilution plate technique following the procedure of Dhingra and Sinclair (1985) [21].

\subsection{Experimental Design and Data Analysis}

The experiment was conducted in the Plant Protection Laboratory of Agrotechnology Discipline, Khulna University. Five replicated petridishes were used for each treatment under each experiment following Completely Randomized Design (CRD). The data were analyzed using STAR (Statistical Tool for Agricultural Research) statistical program.

\section{Results and Discussion}

\subsection{Pathological Survey on Incidence and Severity of Early Leaf Blight of Tomato}

Incidence and severity of early blight varied significantly among the upazila under Bogura district (Figure 1). Significantly highest incidence (85.66\%) and severity $(29.00 \%)$ was recorded from Nandigram upazila and lowest incidence (47.33\%) was recorded in Bogura sadar but the lowest severity (11.66\%) was measured in Dupchanchia upazila. Sony et al. (2017) didn't find any precise 
available information on the distribution of early blight disease in both protected and natural cultivated tomato crop in southern Rajasthan [23]. Therefore they surveyed in three districts of southern Rajasthan viz., Udaipur, Chittorgarh and Rajsamand in open fields as well as in polyhouse. In fields of farmers early blight of tomato was observed moderate to severe form in all surveyed fields with the tune of $35.14 \%$ to $51.98 \%$ severity. In the present study all the fields among upazilas were at least $15 \mathrm{~km}$ apart from each other might be the reason for significantly varying in incidence and severity of early blight due to variation in temperature and humidity of that region whereas Rao et al. (2016) find no significant difference in incidence and severity of early blight when data were taken from the fields within $6 \mathrm{~km}$ apart from each other [24].

\subsection{Pathogenicity Test}

The inoculated fungus produced similar symptoms as observed from where it was isolated and the Koch's postulate was confirmed by re-isolating the same fungus. Thus the causal organism of early blight of tomato under present investigation was confirmed as $A$. solani (Figure 2).

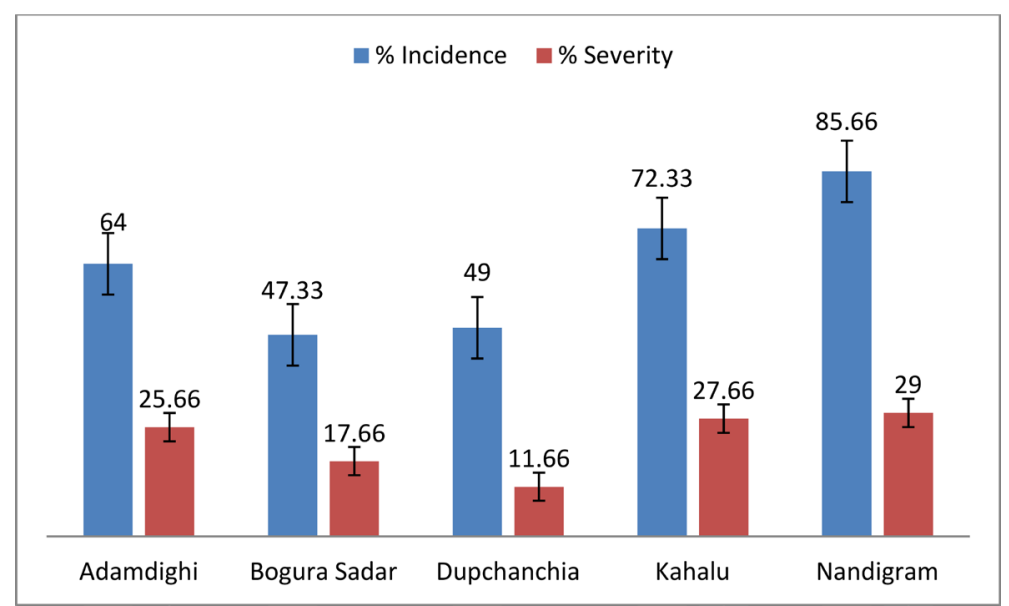

Figure 1. Incidence and severity of early blight of tomato caused by Alternaria solani in different upazilas of Bogura district.

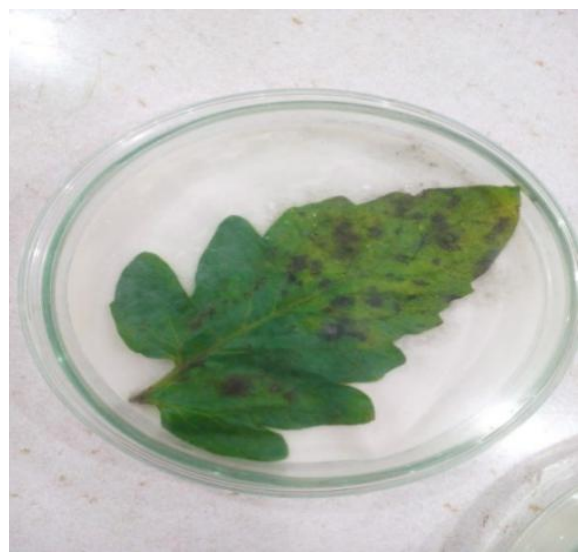

Figure 2. Pathogenicity test of Alternaria solani on excised tomato leaf. 


\subsection{Effect of Different Culture Media on Mycelia Growth of Alternaria solani}

In culture media investigation, various growth media were used for evaluation of nutritional variability and growth pattern of Alternaria solani. In present experiment, growth of Alternaria solani was significantly varied $(\mathrm{P}<0.05)$ indifferent culture media (Table 2).

The data from the table representV-8 juice agar as the most effective supporting medium for the growth of the Alternaria solani, which showed $73.10 \mathrm{~mm}$ diameter of colony growth and the lowest colony growth $(43.00 \mathrm{~mm})$ was recorded in Richard's Agar medium after six days of incubation. On the other hand, mycelial radial growth of $A$. solani on PDA $(71.56 \mathrm{~mm})$ and Asthana and Hawker's agar media $(69.90 \mathrm{~mm})$ very close to V-8 Juice agar media $(73.10 \mathrm{~mm})$ followed by oat meal agar media $(67.60 \mathrm{~mm})$.

The results were disagreed to Koley and Mahapatra (2015) [13] and Ginoya and Gohel (2015) found that PDA was the best for mycelial growth of $A$. solani [25]. Mehta and Prasad (1976) also reported oat meal agar and Richard's medium as better for growth of Alternaria sesame [26]. The study indicated that more growing media could be tested to identify the most suitable medium for the growth of $A$. solani.

\subsection{Effect of Different Culture Media on Sporulation of Alternaria solani}

Conidia production/sporulation was observed in different culture media. Spore production varied significantly in different media ranged from 53,000 - 100,000 spores in six days. Different culture media such as Potato Dextrose Agar, Agar Richard's Agar, Waksman Agar, Corn Meal Agar, Asthana and Hawker's agar, Oat Meal Agar and V-8 Juice Agar Medium was produced 53,000, 67,000, $58,000,53,000,27,000,37,00$ and 100,000 spores, respectively in six days. It was found that V-8 juice agar medium produced the highest number of spores.

Table 2. Effect of different culture media on mycelial growth of Alternaria solani.

\begin{tabular}{cc}
\hline Growth Media & Mycelial Growth (mm) \\
Potato Dextrose Agar (PDA) & $71.56^{\mathrm{ab}}$ \\
Richard's Agar & $43.00^{\mathrm{d}}$ \\
Waksman Agar & $58.30^{\mathrm{c}}$ \\
Corn Meal Agar & $56.70^{\mathrm{c}}$ \\
Asthana and Hawker's Agar & $69.90^{\mathrm{ab}}$ \\
Oat Meal Agar & $67.60^{\mathrm{b}}$ \\
V-8 Juice Agar & $73.10^{\mathrm{a}}$ \\
CV\% & 3.36 \\
Level of Significance & $0.05^{*}$
\end{tabular}

N.B:* indicates that level of significance at $5 \%$. 
Hence in our studyV-8 juice agar medium was the best medium for sporulation of Alternaria solani (Figure 3(a)) though Richard's Agar significantly produced higher number of conidia $\mathrm{cm}^{-2}$ of mycelial culture (Figure 3(b)).

The results agreed to Shabana et al. (2015), they found V-8 Juice Agar Medium best for sporulation of Alternaria solani [27]. Our findings also agreed to Liuchienhui et al. (1997), they found that sporulation was increased in V-8 Juice Agar Medium [28]. On the contrary, Zhu et al. (1985) found that $A$. solani sporulated profusely on corn meal agar media [29].

\subsection{Effect of Different Culture Media on Colony Characteristics of Alternaria solani}

Colony characteristics of Alternaria solani on different media represents in Table 3 and Plate 1. Noticeable variations were observed in Plate 1 due to the effect of components of different growth media. In case of colony color, it was found that greenish black, dark green, olive green, whitish, dark green, greenish and whitish colony with greenish from Potato Dextrose Agar (PDA), Richard's Agar, Waksman Agar, Corn Meal Agar, Asthana and Hawker's agar, Oat Meal Agar and V-8 Juice Agar growth media, respectively. Circular growth margin

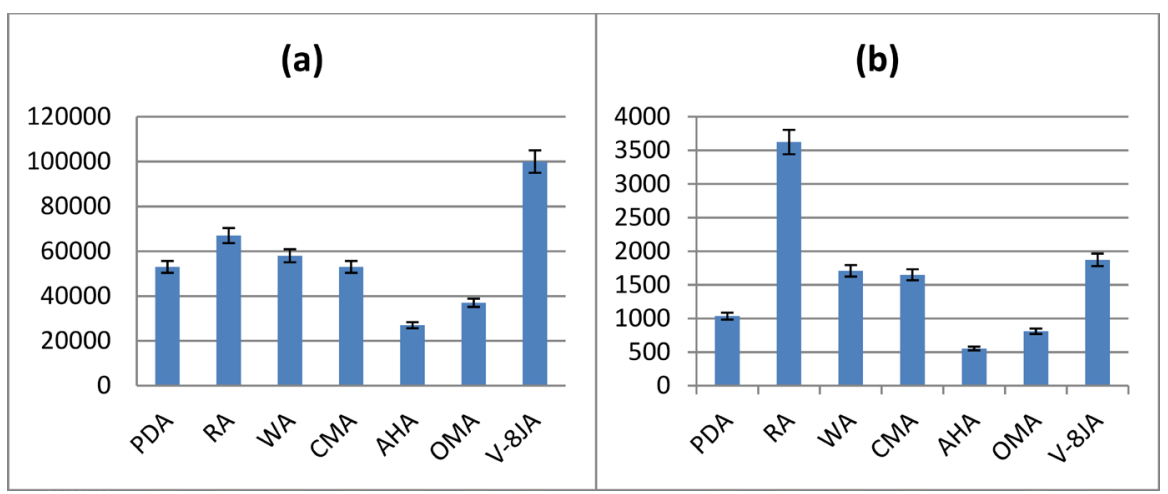

Figure 3. Sporulation of Alternaria solani in different culture media; (a) Number of conidia after six days of inoculation and (b) Number of conidia/ $\mathrm{cm}^{2}$ of colony.

Table 3. Effect of Different Culture Media on Colony characteristics of Alternaria solani.

\begin{tabular}{cccccc}
\hline Growth Media & Colony Color & $\begin{array}{c}\text { Growth } \\
\text { Margin }\end{array}$ & $\begin{array}{c}\text { Growth } \\
\text { Surface }\end{array}$ & $\begin{array}{c}\text { Margin } \\
\text { Topography }\end{array}$ & Zonation \\
\hline Potato Dextrose Agar & Greenish Black & Circular & Smooth & Merged & Yes \\
Richard's Agar & Dark Green & Irregular & Rough & Submerged & No \\
Waksman Agar & Olive Green & Irregular & Smooth & Submerged & Yes \\
Corn Meal Agar & Whitish & Circular & Smooth & Submerged & No \\
Asthana and & Dark Green & Irregular & Rough & Submerged & No \\
Hawker's agar & Greenish & Circular & Rough & Merged & No \\
Oat Meal Agar & Whitish Colony & Circular & Smooth & Cottony-Merged & Yes \\
V-8 Juice Agar & with Greenish & & & & \\
\hline
\end{tabular}



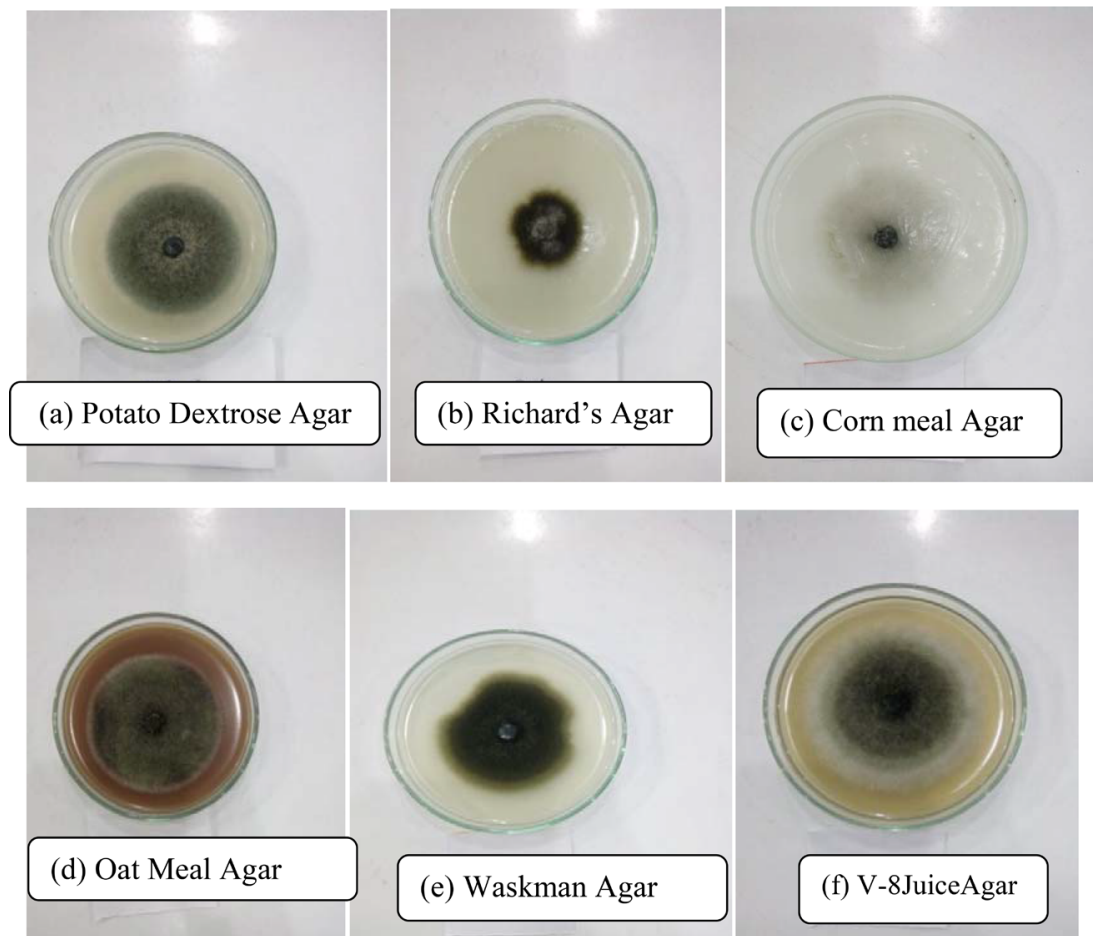

(d) Oat Meal Agar

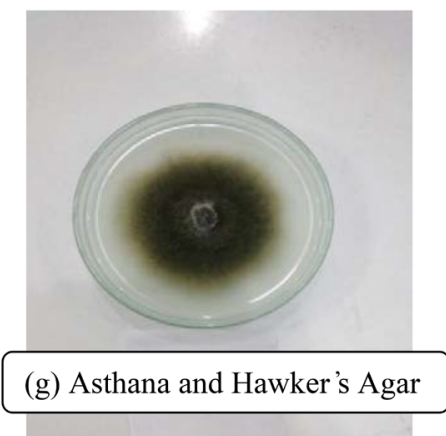

Plate 1. Effect of different culture media on mycelial growth and colony characteristics of Alternaria solani.

was recorded in case of Potato Dextrose Agar, Corn Meal Agar, Oat Meal Agar and V-8 Juice Agar growth media. On the other hand, irregular growth margin was found in Richard's Agar, Waksman Agar and Asthana and Hawker's agar media. If we consider growth surface of $A$. solani, smooth surface was from Potato Dextrose Agar, Waksman Agar, Corn Meal Agar and V-8 Juice Agar media. Whereas, rough growth surface was found in Richard's Agar, Asthana and Hawker's agar and Oat Meal Agar media. In addition margin topography was merged in case of Potato Dextrose Agar and Oat Meal Agar media. However submerged topography was observed in Richard's Agar, Waksman Agar, Corn Meal Agar and Asthana and Hawker's agar media. Only cottony-merged margin was noticed from V-8 Juice Agar media. Finally, zonation was present in case of Potato Dextrose Agar, Waksman Agar and V-8 Juice Agar media. But the fungal growth on Richard's Agar, Corn Meal Agar, Asthana and Hawker's agar and Oat Meal Agar media, created no zonation. 
From our experiment differences in colony color greenish to whitish, margin circular to irregular, growth surface smooth to rough, topography merged to submerged and zonation were found but the findings of Savitha et al. (2013) showed the color of isolates of the Alternaria spp varied from light grey to dark brown [30]. Six isolates demonstrated irregular margins whereas eight gave raised growth. On the other hand, Kumar et al. (2015) found that pigmentation of Alternaria solani varied from brown to black color on different media, light yellow to black color at different temperatures and gray to brown color on different $\mathrm{pH}$ ranges [31].

Another finding of Pipaliya and Jadeja (2008) showed that among 32 isolates of $A$. burnsii had dark brown to black colour growth, 19 have typical black, 20 olive green and nine showed dirty white coloured colonies [32].

\subsection{Effect of Different pH Level on Mycelia Growth of Alternaria solani}

Alternaria solani had shown significant variations $(\mathrm{P}<0.05)$ on different $\mathrm{pH}$ level (Table 4 and Figure 4 and Plate 2). The maximum mycelial growth was recorded at $\mathrm{pH} 6.0(71.70 \mathrm{~mm})$ and the minimum level was found at $\mathrm{pH} 7.5$ $(56.00 \mathrm{~mm})$ after six days of incubation. However, $\mathrm{pH} 5.5(68.50 \mathrm{~mm})$ and $\mathrm{pH}$ $6.5(70.20 \mathrm{~mm})$ were statistically similar to each other, and also findings of $\mathrm{pH}$ $7.0(57.60 \mathrm{~mm})$ was statistically similar with $\mathrm{pH} 7.5(56.00 \mathrm{~mm})$ and $\mathrm{pH} 8.0$ (60.10 mm). pH level 5 to 6.5 gave very closer effect on mycelial growth of $A$. solani after six days of incubation. So, above $\mathrm{pH}$ level (5 to 6.5$)$ is the appropriate for the growth of $A$. solani.

The results agreed to Hubballi et al. (2010), they found that the growth of $A$. alternata was maximum in $\mathrm{pH}$ range of 6.00 - 6.50 [33]. Our findings also agreed to Saeed et al. (1995), they found that Alternaria alternate grow well at pH 6.5 to 7

[34]. On the other hand, Samuel and Govindaswamy (1972) found pH 5.0 as the best for mycelial growth of $A$. solani [35]. Ramjegathesh and Ebenezar (2012)

Table 4. Effect of different $\mathrm{pH}$ level on mycelial growth of Alternaria solani.

\begin{tabular}{cc}
\hline pH Levels & Mycelial Growth (mm) \\
5 & $67.30^{\mathrm{b}}$ \\
5.5 & $68.50^{\mathrm{ab}}$ \\
6 & $71.70^{\mathrm{a}}$ \\
6.5 & $70.20^{\mathrm{ab}}$ \\
7 & $57.60^{\mathrm{cd}}$ \\
7.5 & $56.00^{\mathrm{d}}$ \\
8 & $60.10^{\mathrm{c}}$ \\
CV\% & 3.16 \\
Level of Significance & $0.05^{\star}$ \\
\hline
\end{tabular}

N.B:* indicates that level of significance at $5 \%$. 


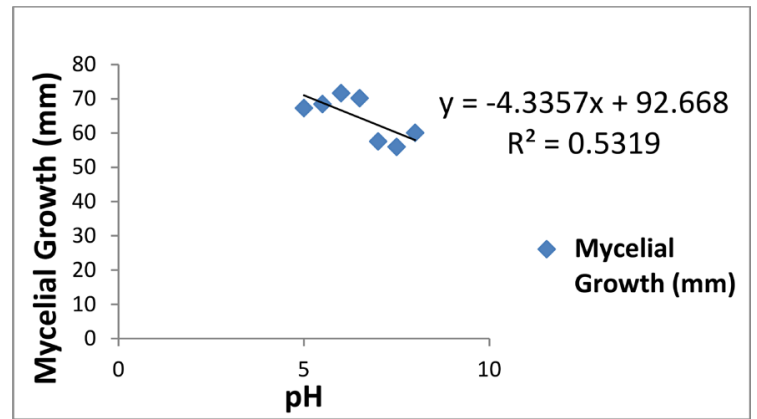

Figure 4. Functional relationship between different $\mathrm{pH}$ level and mycelial growth of $A$. solani.
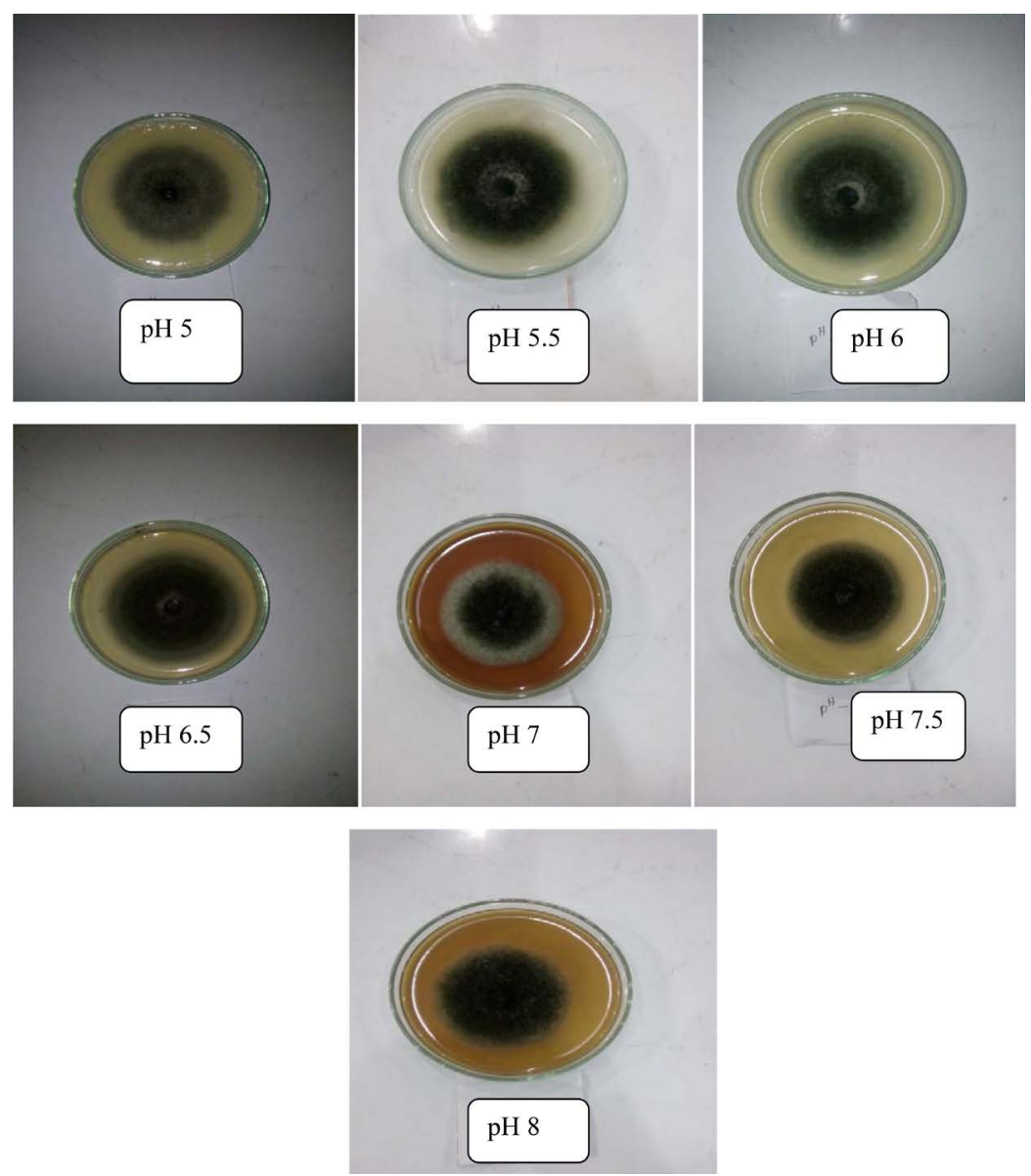

Plate 2. Effect of different $\mathrm{pH}$ level on mycelial growth of Alternaria solani.

also found low $\mathrm{pH}(4-4.5)$ as ideal for the growth of $A$. alternate [36]. Negative functional relationship was observed between $\mathrm{pH}$ level and radial mycelial growth of $A$. solani. That means, increasing $\mathrm{pH}$ reducing mycelial growth (Figure 4) at the rate of 53 percent.

\subsection{Effect of Different Temperature on Mycelial Growth of Alternaria solani}

Different temperature had distinct effect $(\mathrm{P}<0.05)$ on growth of Alternaria so- 
lani (Table 5, Figure 5 and Plate 3). Among the different temperature level, the highest mycelial growth $(72.20 \mathrm{~mm})$ of Alternaria solani was recorded in $25^{\circ} \mathrm{C}$ temperature and the lowest growth $(50.80 \mathrm{~mm})$ were recorded in $35^{\circ} \mathrm{C}$ temperature after six days of incubation. No mycelia growth of Alternaria solani was observed in $40^{\circ} \mathrm{C}$. In case of temperature $20^{\circ} \mathrm{C}$ and $30^{\circ} \mathrm{C}$, mycelial growth of $\mathrm{Al}$ ternaria solani was found $56.30 \mathrm{~mm}$ and $61.20 \mathrm{~mm}$, respectively.

The results agreed to Sharma and Rajak (2003), they found that the optimum temperatures for the growth of Alternaria sp. between $25^{\circ} \mathrm{C}$ to $30^{\circ} \mathrm{C}$ [37]. Temperature above $40^{\circ} \mathrm{C}$ was found adverse for the growth. Our findings also agreed to Kaul and Saxena (1988), they found that the maximum growth of $A$. solani was at $25^{\circ} \mathrm{C}$ with least growth at $35^{\circ} \mathrm{C}$ [38]. Kaur and Aggarwal (2015) also concluded the optimal growth of $A$. macrospora was observed at $25^{\circ} \mathrm{C}$, and no sign of growth was recorded at $45^{\circ} \mathrm{C}$ [39]. From this experiment, it is revealed that $A$. solani cannot survive at $40^{\circ} \mathrm{C}$ temperature. Whereas, $25^{\circ} \mathrm{C}$ temperature is the most surviving temperature of $A$. solani. From Figure 3, negative functional relationship was observed between temperature and radial mycelial growth of $A$. solani. That means, increasing temperature reducing mycelial growth at the rate

Table 5. Effect of different temperature on mycelial growth of Alternaria solani.

\begin{tabular}{cc}
\hline Temperature & Mycelial Growth (mm) \\
\hline $20^{\circ} \mathrm{C}$ & $56.30^{\mathrm{c}}$ \\
$25^{\circ} \mathrm{C}$ & $72.20^{\mathrm{a}}$ \\
$30^{\circ} \mathrm{C}$ & $61.20^{\mathrm{b}}$ \\
$35^{\circ} \mathrm{C}$ & $50.80^{\mathrm{d}}$ \\
$40^{\circ} \mathrm{C}$ & $0.00 \mathrm{e}$ \\
$\mathrm{CV} \%$ & 1.62 \\
Level of Significance & $0.05^{\star}$
\end{tabular}

N.B:* indicates that level of significance at $5 \%$.

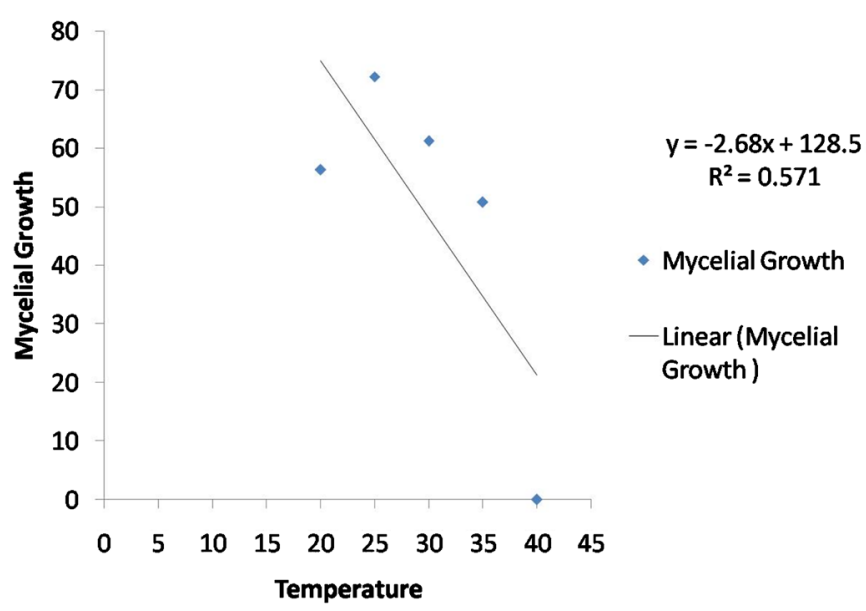

Figure 5. Functional relationship between different temperature and mycelial growth of Alternaria solani. 

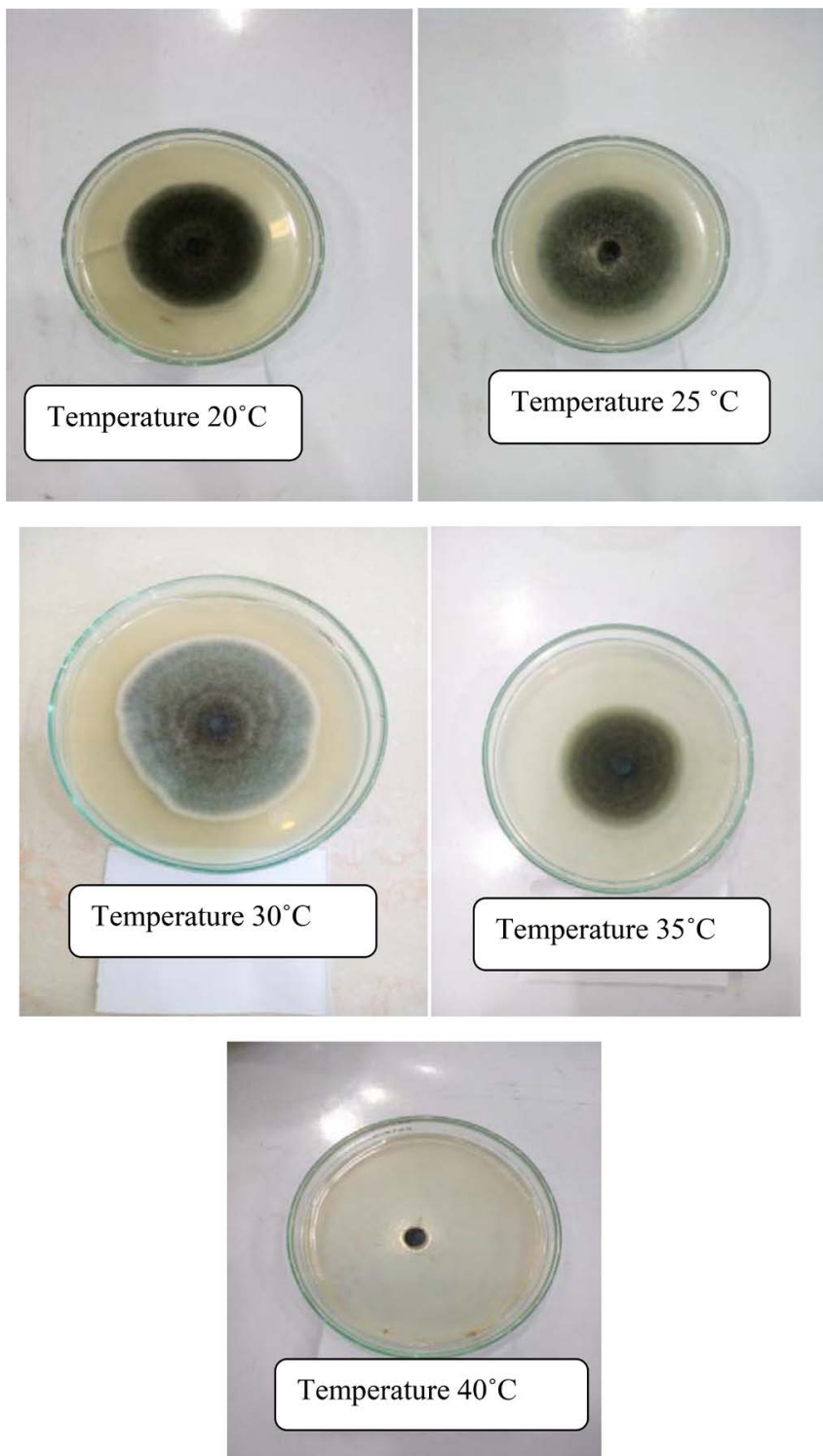

Plate 3. Effect of different temperature on mycelial growth of Alternaria solani.

of 57 percent (Figure 3).

\section{Conclusion}

It may be concluded that among seven tested growth media, the highest mycelial growth was reported from V-8 juice agar medium which was very closer to PDA and Asthana and Hawker's agar media. Similarly, V-8 juice agar medium produced maximum number of spores of Alternaria solani. Hence, V-8 juice agar medium may be considered as the most effective medium for the growth as well as sporulation of the Alternaria solani. In addition, the $\mathrm{pH}$ level 5 to 6.5 was appropriate for the growth of $A$. solani whereas $\mathrm{pH} 6$ produced maximum mycelial growth. In case of temperature, $25^{\circ} \mathrm{C}$ temperature was the most surviving temperature for $A$. solani, in the contrary; the fungus did not grow at all at the temperature of $40^{\circ} \mathrm{C}$. 


\section{Authors' Contributions}

This work was carried out in collaboration among all authors. Author IP conducted the research work and collected all data. Author CM designed and supervised the study. Author MSS executed research plan and designed the study. Author NS executed research plan and managed the literature searches. Author FMA conducted pathological survey, wrote, corrected and edited the manuscript. All authors read and approved the final manuscript.

\section{Conflicts of Interest}

The authors declare no conflicts of interest regarding the publication of this paper.

\section{References}

[1] Chowdhury, B. (1979) Vegetables. 6th Revised Edition, The Director National Book Trust, New Delhi, 45 p.

[2] Musa, L.M., Haroun, K.S. and Raja, U.C. (2007) Performance of Tomato Plants Under Different Levels of Organic Compost during Dry Seasons in Northern Nigeria. Journal of Arid Agriculture, 21, 591-601.

[3] Bangladesh Bureau of Statistics (BBS) (2016) All Crops Summary 2008-2009. Statistics Division, Ministry of Planning, Govt. of Peoples' Republic of Bangladesh, Dhaka, 1-7.

[4] Food and Agriculture Organization of the United Nations (2016) Food and Agriculture Organization Corporate Statistical Database (FAOSTAT). http://www.fao.org/faostat/en/\#data/QC

[5] Halder, N.K., Saha, M.K., Kabir, A.H.M.F., Sarker, J.U. and Rahman, M.J. (2003) Response of Summer Tomato to Hormone and Planting Time at Hill Slope. Pakistan Journal of Biological Sciences, 6, 146-148. https://doi.org/10.3923/pjbs.2003.146.148

[6] Balanchard, D. (1992) A Colour Atlas of Tomato Diseases. Wolfe Pub. Ltd., Brook House, London, 298.

[7] Datar, V.V. and Mayee, C.D. (1981) Assessment of Loss in Tomato Yield Due to Early Blight. Indian Phytopathology, 34, 191-195

[8] Mathur, K. and Shekhawat, K.S. (1986) Chemical Control of Early Blight in Kharif Sown Tomato. Indian Journal of Mycology and Plant Pathology, 16, 235-238.

[9] Sherf, A.F. and MacNab, A.A. (1986) Vegetable Diseases and Their Control. Wiley, New York.

[10] Neergaard, P. (1945) Danish Species of Alternaria and Stemphylium: Taxonomy, Parasitism, Economic Significance. Oxford University Press, London, 260-287.

[11] Ellis, M.B. and Gibson, I.A.S. (1975) Alternaria solani No. 45 set 48. Common Wealth Mycological Institute, Kew, Surrey, UK.

[12] Rotem, J. (1994) The Genus Alternaria Biology, Epidemiology, and Pathogenicity. American Phytopathological Society, St. Paul, 48-203.

[13] Koley, S. and Mahapatra, S.S. (2015) Evaluation of Culture Media for Growth Characteristics of Alternaria solani, Causing Early Blight of Tomato. Journal of Plant Pathology and Microbiology, S1, 5. https://doi.org/10.4172/2157-7471.1000S1-005 
[14] Diba, K., Kordbacheh, P., Mirhendi, S.H., Rezaie, S. and Mahmoudi, M. (2007) Identification of Aspergillus Species Using Morphological Characteristics. Pakistan Journal of Medical Sciences, 23, 867-872.

[15] Zain, M.E., Razak, A.A., El-Sheikh, H.H., Soliman, H.G. and Khalil, A.M. (2009) Influence of Growth Medium on Diagnostic Characters of Aspergillus and Penicillium Species. African Journal of Microbiology Research, 3, 280-286.

[16] Stevenson, R.E. and Packer, S.P. (1988) Effect of Radiation Temperature and Moisture on Conidial Germination of Alternaria solani. Phytopathology, 78, 926-930. https://doi.org/10.1094/Phyto-78-926

[17] Rodriguez, A.C.M. and Santana, C.R. (1991) Effectivity of New Culture Media and Temperature on the Growth in Vitro of Alternaria solani. Centro Agrícola, 18, 86-88.

[18] Prasad, B., Dutt, B.L. and Nagaich, B.B. (1973) Inducing Sporulation in Alternaria solani I, Effect of Water Treatment. Mycopathologia, 49, 141-146. https://doi.org/10.1007/BF02050856

[19] Rath, G.C. and Padhi, N.N. (1973) Sporulation of Alternaria solani in Pure Culture. Indian Phytopathology, 26, 495-501.

[20] Tong, Y.H., Liang, J.N. and Xu, J.Y. (1994) Study on the Biology and Pathogenicity of Alternaria solani on Tomato. Journal Jiangsu Agricultural College, 15, 29-31.

[21] Dhingra, O.D. and Sinclair, J.B. (1995) Basic Plant Pathology Methods. CRC Press, Boca Raton, 132-163. https://doi.org/10.1201/9781315138138

[22] Anonymous (1968) Plant Pathologist's Pocketbook. Commonwealth Mycological Institute, Great Britain, 394-395.

[23] Soni, R., Tanwar, V.K. and Yadav, S.M. (2017) Survey and Screening of Genotypes against Alternaria solani Caused Early Blight of Tomato in Southern Part of Rajasthan. Chemical Science Review and Letters, 6, 1483-1489.

[24] Rao, S., Danish, S., Keflemariam, S., Tesfagergish, H., Tesfamariam, R. and Habtemariam, T. (2016) Pathological Survey on Disease Incidence and Severity of Major Diseases on Tomato and Chilli Crops Grown in Sub Zoba Hamelmalo, Eritrea. International Journal of Research Studies in Agricultural Sciences, 2, 20-31. https://doi.org/10.20431/2454-6224.0201004

[25] Ginoya, C.M. and Gohel, N.M. (2015) Cultural and Morphological Variability among the Isolates of Alternaria alternata (Fr.) Keissler, Incitant of Fruit Rot of Chilli. International Journal of Plant Protection, 8, 118-125. https://doi.org/10.15740/HAS/IJPP/8.1/118-125

[26] Mehta, P.P. and Prasad, R.N. (1976) Investigations on Alternaria sesami Causing Leaf Blight of Til. Proceedings of the Bihar Academy of Sciences, 24, 104-109.

[27] Shabana, Y.M., AbouTabl, A.H. and Al-Farhan, I.M.H. (2015) Effect of Culture Media on Mycelia Growth and Sporulation of Two Isolates of Alternaria solani, the Causal Agent of Early Blight Disease of Tomato. Journal of Plant Protection and Pathology, 6, 1135-1141. https://doi.org/10.21608/jppp.2015.74714

[28] Liuchienhui, W., Liu, C.H. and Wu, W.S. (1997) Chemical and Biological Control of Tomato Early Blight. Plant Pathology Bulletin, 6, 132-140.

[29] Zhu, Z.Y., Huang, Y.M. and Li, Y.H. (1985) An Efficient Technique for Inducing Profuse Sporulation of Alternaria solani in Pure Culture. Acta Mycologica Sinica, 4, 180-181.

[30] Savitha, A.S., Naik, M. K. and Kumar, A.K. (2013) Cultural, Morphological, Physiological and Pathogenic Diversity among the Isolates of Alternaria sp. Incitant of 
Blight Disease of sesame. Journal of Mycopathological Research, 51, 259-265.

[31] Kumar, V., Kumar, K.P. and Kumar, K.M. (2015) Study of Variability and Sporulation by Isolates of Alternaria solani of Lycopersicon esculentum (MILL). Asian Journal of Science and Technology, 6, 1264-1270.

[32] Pipaliya, B.H. and Jadeja, K.B. (2008) Cultural Variability and Mancozeb Sensitivity of Different Isolates of A. burnsii L. Journal of Indian Mycology and Plant Pathology, 38, 121-122.

[33] Hubballi, M., Nakkeeran, S., Raguchander, T., Anand, T. and Samiyappan, R. (2010) Effect of Environmental Conditions on Growth of Alternaria alternata Causing Leaf Blight of Noni. World Journal of Agricultural Sciences, 6, 171-177.

[34] Saeed, M.A., Ahmad, A. and Khan, M.A. (1995) Effect of Different Media, Temperature, pH Levels, Nitrogen and Carbon Sources on the Growth of Alternaria spp. Pakistan Journal of Plant Pathology, 7, 210-211.

[35] Samuel, G.S. and Govindaswamy, C.V. (1972) Effect of Vitamins and Levels of pH on the Growth and Sporulation of Alternaria solani, the Causal Agent of the Leaf Blight Disease of Sesame. Indian Journal of Mycology and Plant Pathology, 2, 185-186.

[36] Ramjegathesh, R. and Ebenezar, E.G. (2012) Morphological and Physiological Characters of Alternaria alternata Causing Leaf Blight Disease of Onion. International Journal of Plant Pathology, 3, 34-44. https://doi.org/10.3923/ijpp.2012.34.44

[37] Sharma, R. and Rajak, R.C. (2003) Keratinophilic fungi: Natural Keratin Degrading Machines! Their Isolation, Identification and Ecological Role. Resonance, 8, 28-40. https://doi.org/10.1007/BF02837919

[38] Kaul, A.K. and Saxena, H.K. (1988) Physiologic Specialization in Alternaria solani Causing Early Blight of Tomato. Indian Journal of Mycology Plant Pathology, 18, 128-132

[39] Kaur, M. and Aggarwal, N.K. (2015) Effect of Different Temperature on Growth of Alternaria macrospora Isolated from Parthenium Weed. Plant Science Weed, 5, 50-54. 